\title{
On-demand Detachment of Maleimide Derivatives on Cysteine to Facilitate (Semi)Synthesis of Challenging Proteins
}

Ganga B. Vamisetti, " Gandhesiri Satish," Prasad Sulkshane, Guy Mann, Michael H. Glickman and Ashraf Brik*

abrik@technion.ac.il

(\# equal contribution) 


\begin{abstract}
The maleimide group is a widely used reagent for bio-conjugation of peptides, proteins and oligonucleotides employing Michael addition and Diels-Alder cycloaddition reactions. However, the utility of this functionality in chemical synthesis of peptides and proteins remains unexplored. We report, for the first time that $\mathrm{Pd}^{\mathrm{II}}$ complexes can mediate the efficient removal of various maleimide derivatives in aqueous conditions. Maleimide removal by $\mathrm{Pd}^{\mathrm{II}}$ was applied for the synthesis of two ubiquitin activity-based probes (UbABPs) employing solid phase chemical ligation (SPCL). SPCL was achieved through a sequential three segments ligation on a polymer support via a maleimide anchor. The obtained probes successfully formed the expected covalent complexes with deubiquitinating enzymes (DUBs) USP2 and USP7, highlighting the use of our new method for efficient preparation of unique synthetic proteins. Importantly, we demonstrate the advantages of our newly developed method for the protection and deprotection of native cysteine with a maleimide group in a peptide fragment derived from thioredoxin-1 (Trx-1) obtained via intein based expression to enable ligation/desulfurization and subsequent disulfide bond formation in a one-pot process.
\end{abstract}




\section{Introduction}

Maleimide is a ubiquitous functionality often used for bio-conjugation of peptides, proteins and oligonucleotides due to its relative high stability, selectivity and electrophilic properties. ${ }^{1}$ Specifically, maleimide is employed as a Michael acceptor for conjugating thiols or dienophiles for Diels-Alder cycloadditions. Maleimide chemistry allows the production of fluorescently labeled proteins, ${ }^{2}$ antibody-drug conjugates, ${ }^{3}$ PEGylated proteins, ${ }^{4}$ protein-DNA hybrids, ${ }^{5}$ and cyclic peptides among other complex conjuagtes. ${ }^{6}$ Despite its wide application, there are still some limitations regarding the stability of maleimide based linkers. Maleimides are susceptible to the retro-Michael reaction, which cleaves the thioether linkage under a reducing environment, leading to the loss of cargo. ${ }^{7}$ Therefore, most of the efforts have been focused on preventing the retro-Michael reaction in order to stabilize the maleimide conjugates. ${ }^{8}$ Another disadvantage is that some antibody-drug conjugates connected through cysteine-maleimide chemistry require additional linkers that can be cleaved either enzymatically ${ }^{9}$ or chemically ${ }^{10}$ to release the payload in tumor sites. Developing on demand detachment of the maleimide linkage has potential for expanding the utility of maleimide based linkers for antibody-drug conjugates and for chemical proteomics. ${ }^{11}$ In addition, such an approach might find useful applications in peptide and protein syntheses employing the maleimide as a reversible protecting group and as a cleavable linker.

Chemical protein synthesis permits unlimited site specific modifications of the protein target such as the introduction of posttranslational modifications (PTMs), D-amino acids, affinity and fluorophore tags. ${ }^{12}$ However, often the selection of protecting groups (PGs) 
is highly crucial for achieving successful synthesis of the target protein. ${ }^{13}$ In recent years our group has made tremendous efforts to expand this chemical toolbox, predominantly by developing palladium mediated efficient cleavage of several PGs to facilitate chemical peptide and protein synthesis. ${ }^{14}$ These PGs have enabled sequential ligation, ${ }^{15}$ selective desulfurization, and one-pot disulfide bond formation. ${ }^{16}$ This chemistry was also extended for introducing solubilizing tags ${ }^{17}$ and new linkers ${ }^{18}$ for in vitro and cellular applications. Despite their importance, the requirement for pre-installation of these PGs during synthesis of peptide segments (using SPPS), limits their applicability in particular when dealing with recombinant peptide fragments. Therefore, the development of reagents which enable on demand attachment/detachment of free Cys residues under aqueous conditions is of great interest. Despite some progress in this direction the current methods have limitations. For example, the phenacyl group was used as a Cys PG for expressed fragments to enable protein semisynthesis. ${ }^{19}$ Similarly, the trityl group was used as Cys PG to facilitate disulfide bond formations. ${ }^{20}$ However, the instability of phenacyl group when using methoxy amine during Thz opening, ${ }^{19 b}$ and the instability of the trityl PG during desulfurization makes these methods less attractive. ${ }^{19 \mathrm{c}}$ In addition, both methods require organic solvents for either the protection or deprotection step, which have the potential to affect peptide solubility and makes such an approach incompatible with one-pot synthesis. Therefore, the development of more efficient reagents, specifically those that are stable under native chemical ligation (NCL)/desulfurization conditions and compatible with one-pot deprotection/disulfide bond formation for protein (semi)synthesis would have useful applications. 
The structural resemblances between the acetamidomethyl (Acm) and maleimide PGs, inspired us to investigate the cleavage reaction of the latter PG using palladium chemistry. Herein, we demonstrate for the first time that $\mathrm{Pd}^{\mathrm{II}}$ complexes mediate the efficient cleavage of maleimide PG on Cys under aqueous conditions. We further show the use of maleimide as a stable linker during solid phase chemical ligation (SPCL) for successful synthesis of ubiquitin activity-based probes (Ub-ABPs) for selective labeling of two different deubiquitinating enzymes (DUBs). In addition, we applied our strategy for the protection and deprotection of native Cys side chains in a peptide fragment obtained via intein based expression to enable the semisynthesis of the thioredoxin-1 (Trx-1) protein by means of ligation/desulfurization and disulfide bond formation in onepot reaction.

\section{Results and Discussion}

To examine the potential of maleimide as a $\mathrm{PG}$, we prepared a model peptide $\mathbf{1}$ (LYRAGC(N-Me.Mal)LYRAG), where Cys was masked with the $N$-methyl maleimide group ( $N$-Me.Mal), (Scheme 1). This peptide was initially treated with 10 equiv of $\mathrm{PdCl}_{2}$ in $6 \mathrm{M} \mathrm{Gn} \cdot \mathrm{HCl}, \mathrm{pH} 7.3$ at $37{ }^{\circ} \mathrm{C}$. Gratifyingly, the reaction furnished the unprotected peptide with a complete conversion in about $4 \mathrm{~h}$ (Figure S2B). Encouraged by this result, we examined the influence of other metal complexes on the maleimide decaging reaction. However, none of the examined metal complexes (AuCl, $\mathrm{K}_{2} \mathrm{PtCl}_{6}, \mathrm{NiCl}_{2}, \mathrm{CuCl}_{2}$, and $\mathrm{FeCl}_{3}$ ) was suitable, highlighting the specific role of $\mathrm{Pd}$ complex in this reaction (Figure $\mathrm{S} 3 \mathrm{~B})$. We then turned our attention to find a better Pd complex, testing different complexes such as $[\mathrm{Pd}(\mathrm{allyl}) \mathrm{Cl}]_{2}, \mathrm{Pd}_{2}(\mathrm{dba})_{3}, \mathrm{Pd}\left(\mathrm{PPh}_{3}\right)_{4}, \mathrm{Pd}(\mathrm{OAc})_{2}, \mathrm{Cl}_{4} \mathrm{Na}_{2} \mathrm{Pd}$, and $\mathrm{PdCl}_{2}$ which among them gave the best results (Figure S4B). Aiming to improve the reaction 
efficiency, we investigated the effect of additives for improving the kinetics of the reaction. When 50 equiv of $\mathrm{MgCl}_{2}$ was added along with 10 equiv of $\mathrm{PdCl}_{2}$ in $6 \mathrm{M}$ $\mathrm{Gn} \cdot \mathrm{HCl}, \mathrm{pH} 7.3$ at $37{ }^{\circ} \mathrm{C}$, the reaction was drastically improved and produced quantitatively the decaged peptide within 45 min (Figure S5B). The addition of excess $\mathrm{MgCl}_{2}$ could play various roles including preventing the non-productive chelation of the palladium to the side chain reactive functional groups ${ }^{21,15 d}$ as well affecting the chemistry of Pd by possibly forming in situ $\left[\mathrm{PdCl}_{4}\right]^{2-} \cdot{ }^{22}$ Using additional additives such as 4mercaptophenylacetic acid (MPAA), tris(2-carboxyethyl)phosphine (TCEP), GSH, $\mathrm{NaHSO}_{3}$ and $\mathrm{Na}_{2} \mathrm{~S}_{2} \mathrm{O}_{5}$ did not improve the reaction (Figure $\mathrm{S} 5 \mathrm{~B}$ ). Optimization of the reaction buffer indicated that $6 \mathrm{M} \mathrm{Gn} \cdot \mathrm{HCl}$ facilitated the fastest reaction (Figure $\mathrm{S} 6 \mathrm{~B}$ ), an observation we have also made in previous systems. ${ }^{15 \mathrm{~d}} \mathrm{We}$ therefore concluded that the use of 10 equiv of $\mathrm{PdCl}_{2}, 50$ equiv of $\mathrm{MgCl}_{2}$ in $6 \mathrm{M} \mathrm{Gn} \cdot \mathrm{HCl}$, pH 5.5 (pH reduction after addition of the $\mathrm{MgCl}_{2}$ ) at $37{ }^{\circ} \mathrm{C}$ affords the best results for this reaction.

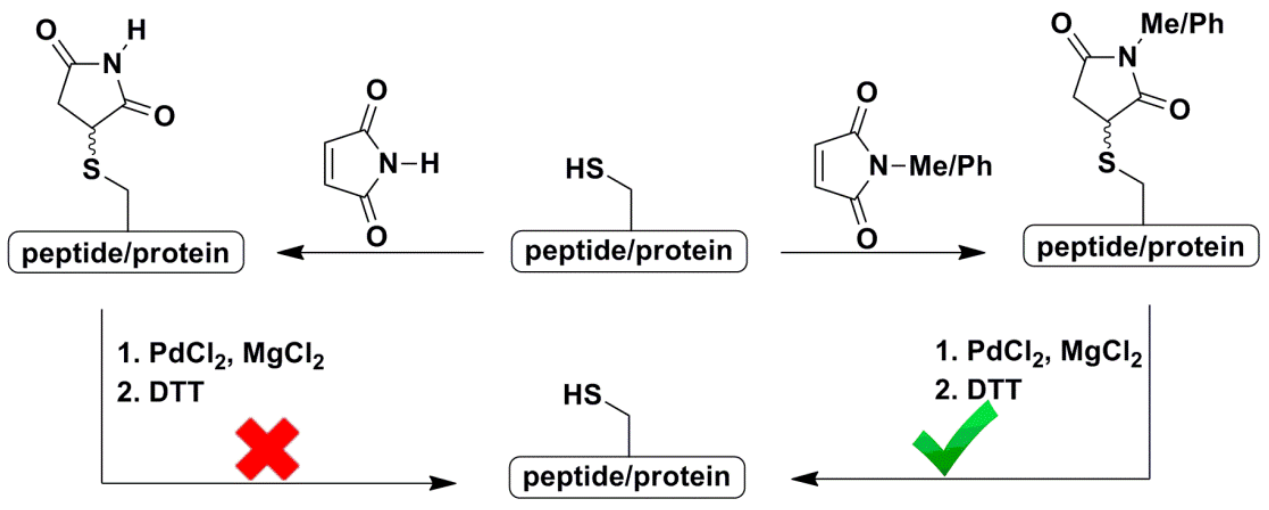

Scheme 1. Schematic representation of installation and removal of maleimide PGs on Cys in peptides and proteins.

Under our established conditions, we examined the feasibility for the cleavage of additional maleimide derivatives such as the $N$-phenyl substituted maleimide. We 
therefore prepared the model peptide 2 (LYRAGC( $N$-Phe.Mal)LYRAG) and examined its behavior under our optimized conditions (Figure S9B). The decaged peptide was obtained with a complete conversion within $45 \mathrm{~min}$, similarly to peptide 1 . In contrast, the unsubstituted maleimide in model peptide 3 (LYRAGC(Mal)LYRAG) was completely stable under Pd cleavage conditions (Figure S9C), which clearly emphasizes the requirement of the phenyl or methyl substitution on the imide group to facilitate cleavage by $\mathrm{Pd}$.

In order to gain insight into the reaction mechanism, we synthesized model peptide 4 (LYRAGC(Mal.LYRAG)LYRAG), where the maleimide group was connected with a short peptide (Figure 1A). Peptide 4 was subjected to our cleavage conditions to give two peptide segments; LYRAGCLYRAG and Mal.LYRAG-[PdCl $]^{2-}$ complex. Previously it has been show that the abstraction of the acidic hydrogen from the sulfhydryl side chain of Cys ( $\left.\mathrm{S}^{t} \mathrm{Bu}\right), \mathrm{Cys}(\mathrm{Acm})$, and Cys (Trt) leads to $\beta$-elimination to cleave the thiol bond. ${ }^{23}$ In a different study, it has been shown that $\mathrm{Pd}$ is able to coordinate the free imide in the succinimide based derivative and generate a palladium catalyst for a cross coupling reaction. ${ }^{24}$ Based on this information and our results, we propose a plausible mechanism for the cleavage of the maleimide group, as depicted in Figure 1D. In case of $\mathrm{N}$ substituted maleimide, the chelation of the Pd complex between the thiol and carbonyl groups trigger $\beta$-elimination to cleave the $\mathrm{C}-\mathrm{S}$ bond and form the thiol-Pd and maleimidePd complexes, respectively. The thiol-Pd complex, upon treatment with DTT liberates the free thiol. In case of the unsubstituted maleimide, the free imide group is susceptible to chelation with the Pd to form an unproductive complex. 

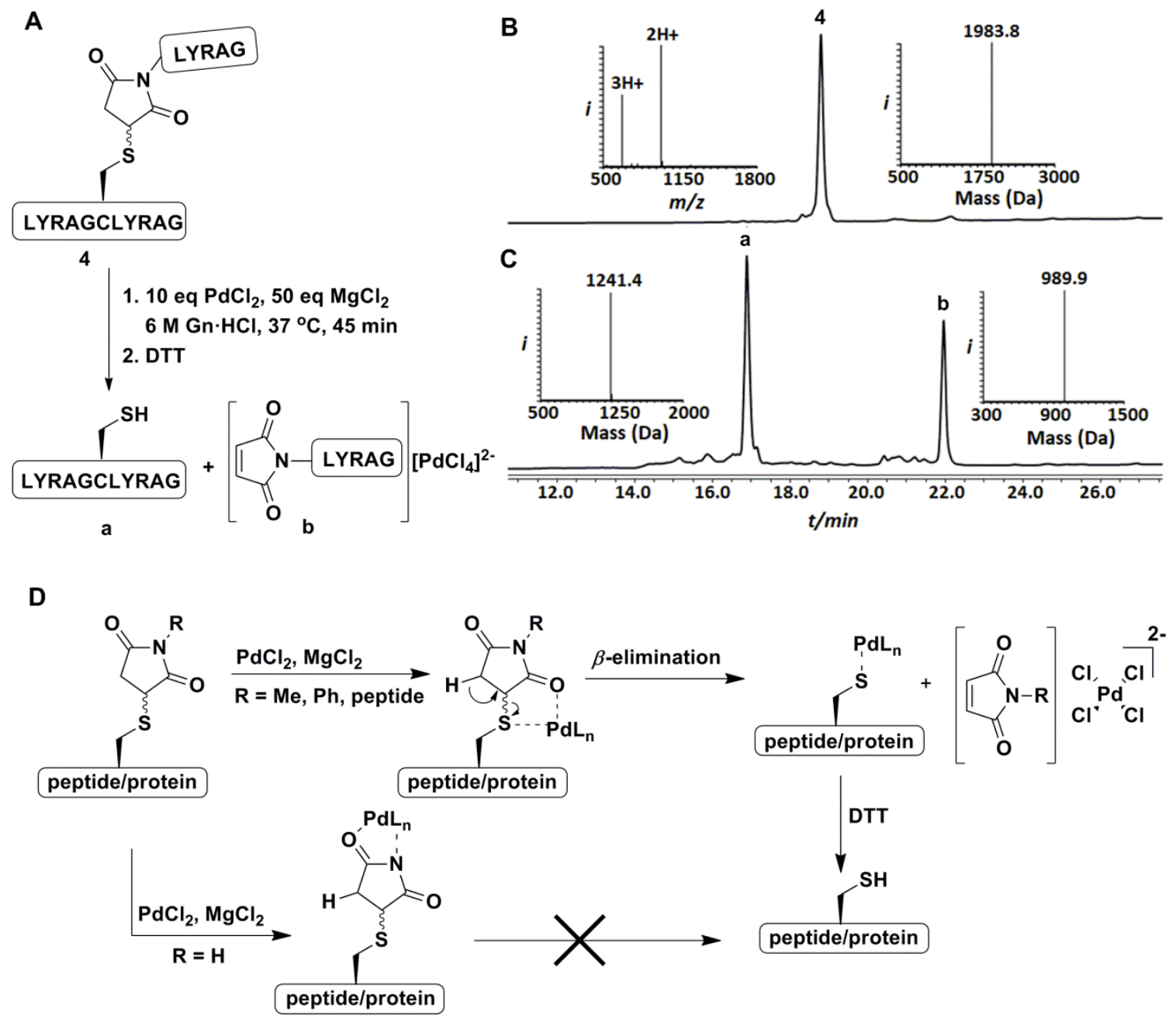

Figure 1. (A) Cleavage of maleimide PG from peptide 4 under optimized conditions. (B) HPLC-MS analysis of the purified model peptide 4 with an observed mass $1983.8 \pm 0.1$ Da (calcd 1984.3 Da, average isotopes). (C) Cleavage of model peptide 4 under optimized conditions. Peak a corresponds to the decaged fragment (LYRAGCLYRAG) with an observed mass $1241.4 \pm 0.1 \mathrm{Da}$ (calcd 1242.5 Da, average isotopes). Peak b corresponds to the complex of $\left[\mathrm{PdCl}_{4}\right]^{2-}$ with (Mal.LYRAG) fragment with an observed mass $989.9 \pm 0.1 \mathrm{Da}$ (calcd $990.1 \mathrm{Da}$, average isotopes). (D) A proposed mechanism for the cleavage of the maleimide group. 


\section{Palladium mediated orthogonal cleavage of Thiazolidine and Maleimide}

In sequential NCL, masking of the $N$-terminal Cys residue of a peptide fragment by thiazolidine (Thz) is highly desirable to avoid peptide cyclization or polymerization. The cleavage of Thz serving as a PG or linker was reported by our group under $[\mathrm{Pd}(\text { allyl }) \mathrm{Cl}]_{2}$ and GSH conditions. ${ }^{18}$ To examine the orthogonality between the Thz and the maleimide PGs, we synthesized model peptide 5 (Thz-LYRAGC(N-Me.Mal)LYRAG), bearing a $N$ terminal Thz and methyl maleimide PGs, (Figure 2A). We then treated this peptide with $[\mathrm{Pd}(\text { allyl }) \mathrm{Cl}]_{2}$ and $\mathrm{GSH}$ in $6 \mathrm{M} \mathrm{Gn} \cdot \mathrm{HCl}, \mathrm{pH} 7.3$ at $37^{\circ} \mathrm{C}$. After $45 \mathrm{~min}$, we observed the full conversion of the Thz to the free $N$-terminal Cys, while keeping the maleimide PG completely intact (Figure 2B). However, when model peptide $\mathbf{5}$ was treated under the optimized conditions, we observed unmasking of the maleimide where the Thz remained stable $(88 \%)$ along with traces of product having both the Thz and maleimide unmasking (12\%) (Figure 2C). This example demonstrates the influence of the specific Pd complex and additive in achieving selective unmasking of two different PGs under aqueous conditions. 


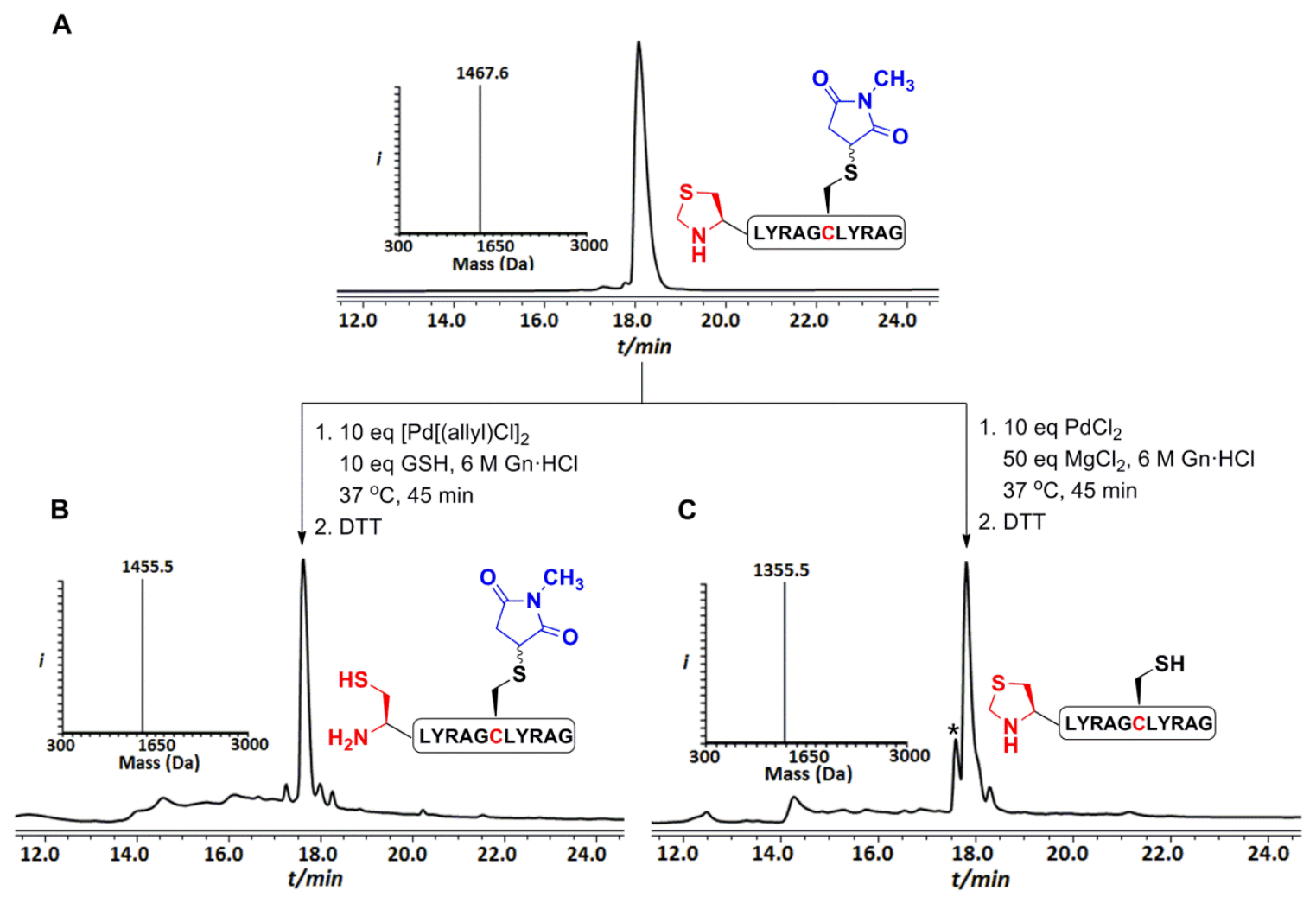

Figure 2. Pd-mediated orthogonal cleavage between the Thz and the maleimide PGs. HPLC-MS analysis: (A) Purified model peptide 5 with an observed mass 1467.6 $\pm 0.1 \mathrm{Da}$ (calcd 1467.7 Da, average isotopes). (B) Crude product after Thz deprotection with an observed mass 1455.5 \pm 0.1 Da (calcd 1455.6 Da, average isotopes). (C) Crude product after the maleimide deprotection with an observed mass $1355.5 \pm 0.1 \mathrm{Da}$ (calcd 1356.6 Da, average isotopes). * corresponds to the product with the deprotection of both Thz and maleimide PGs.

\section{The maleimide linker facilitates SPCL}

To date, the majority of ligation schemes in chemical protein synthesis have been conducted in aqueous solutions. ${ }^{12 a, 25}$ However, the shortcomings like handling losses, multiple HPLC purifications, and lyophilization steps prolong synthesis time and limit 
the construction of large proteins. Hence, several groups including ours have reported different linkers to enable NCL/desulfurization on the solid support. ${ }^{26}$ The success of SPCL relies on the choice of the polymer support, the linker used, NCL/desulfurization and cleavage conditions.

Having established conditions for the selective conversion of the Thz to Cys against the maleimide PG in model peptide 5, we wondered whether the maleimide could be employed to generate a suitable linker for SPCL (Figure 3). We chose the known PEGA resin as a solid support due to its high swelling properties and compatibility in aqueous buffers. $^{27}$ Initially, the maleimide linker was attached to the PEGA polymer support through a spacer of two alanine residues. To enable SPCL for a model system, three peptide segments 6 (Thz-LYRAGLYRAG-Cys), 7 (Thz-LYRAGLYRAG-Nbz (Nbz is $N$-acylbenzimidazolinone), ${ }^{28}$ and 8 (LYRAGCLYRAG-Nbz) were prepared by standard Fmoc-SPPS (Figure S12). In the first step, peptide segment 6 was immobilized to the maleimide bearing solid support via a covalent bond within minutes and subsequently treated with $\mathrm{Pd}[(\text { allyl }) \mathrm{Cl}]_{2}$ and GSH to convert the Thz to the $N$-terminal free Cys. After quenching the polymer support with DTT, the first ligation was performed with peptide 7 in presence of MPAA and TCEP for $5 \mathrm{~h}$. Again, the solid support was treated with $[\mathrm{Pd}(\text { allyl }) \mathrm{Cl}]_{2}$ and $\mathrm{GSH}$ to give the $N$-terminal free Cys for the subsequent ligation with peptide segment 8 . In the final step, the solid support was subjected to maleimide cleavage to liberate polypeptide 9 . The entire process took $\sim 13 \mathrm{~h}$ for the 6 steps and resulted in $46 \%$ isolated yield of product. 

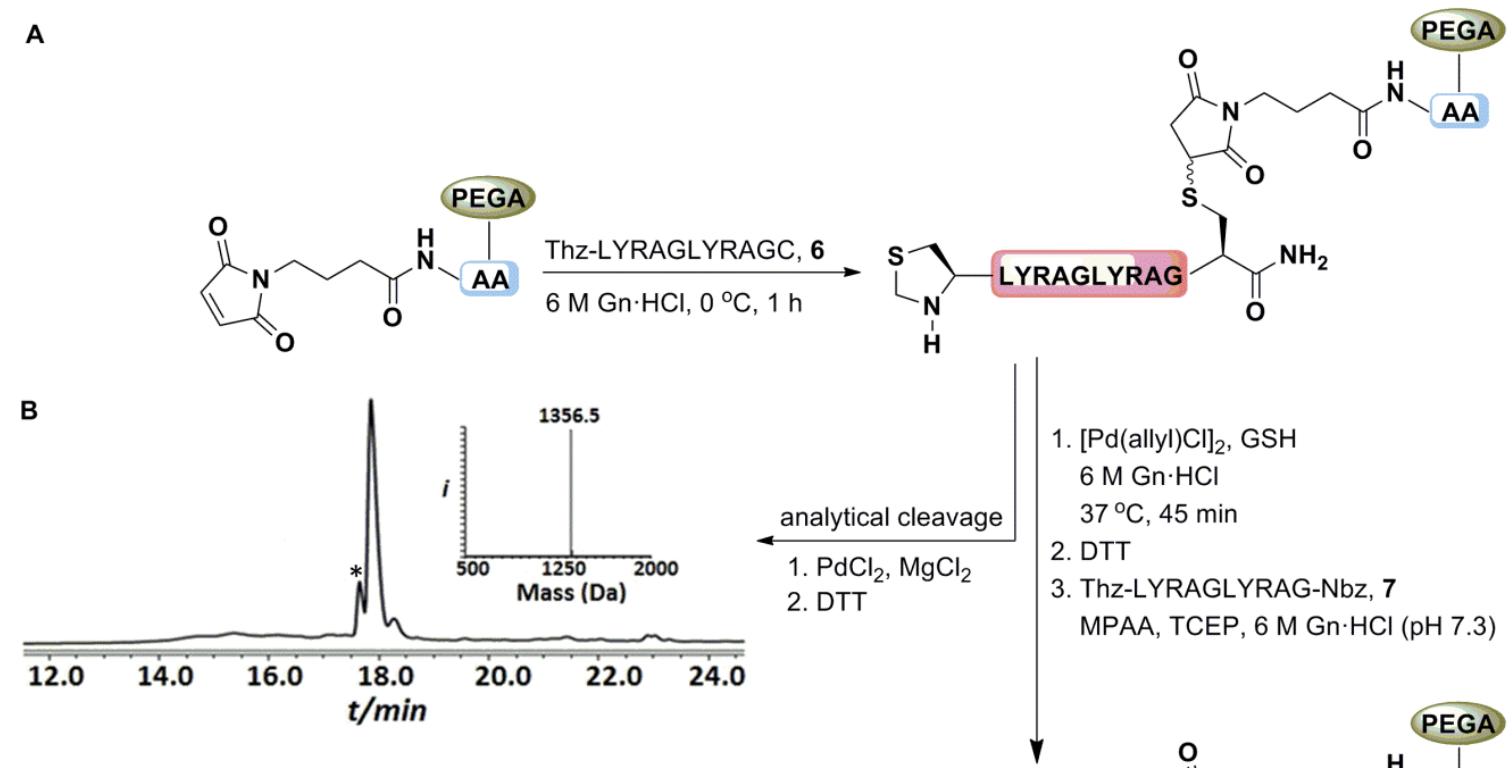

1. $[\mathrm{Pd}(\mathrm{allyl}) \mathrm{Cl}]_{2}, \mathrm{GSH}$ $6 \mathrm{M} \mathrm{Gn} \cdot \mathrm{HCl}$ $37^{\circ} \mathrm{C}, 45 \mathrm{~min}$ 2. DTT

3. Thz-LYRAGLYRAG-Nbz, 7 MPAA, TCEP, $6 \mathrm{M} \mathrm{Gn} \cdot \mathrm{HCl}(\mathrm{pH} 7.3)$

C

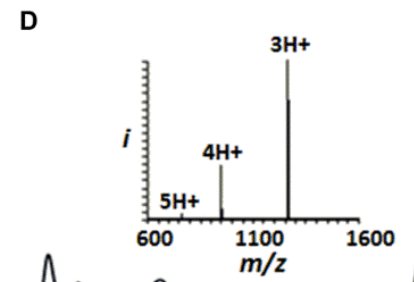

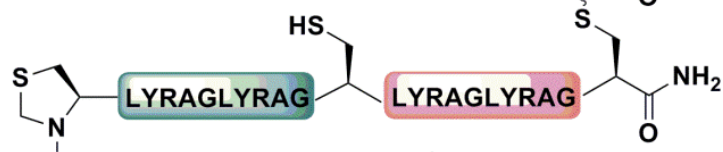

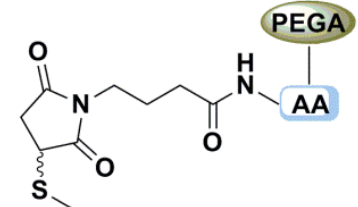

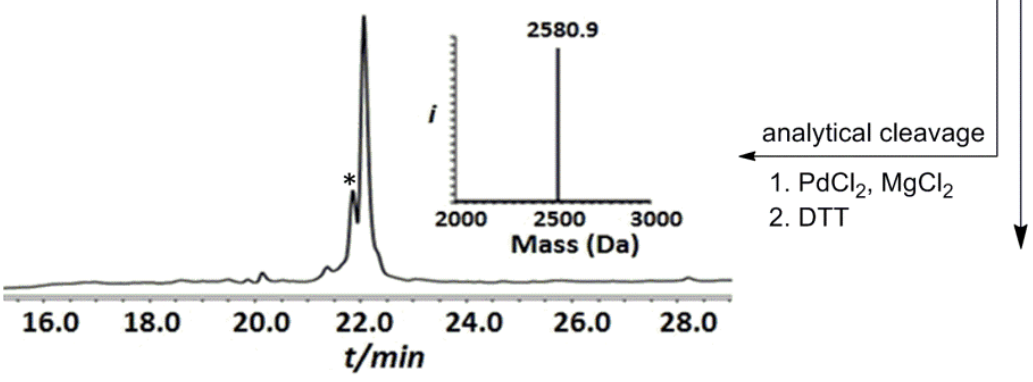

1. $[\mathrm{Pd}(\text { allyl }) \mathrm{Cl}]_{2}, \mathrm{GSH}$ $6 \mathrm{M} \mathrm{Gn} \cdot \mathrm{HCl}$ $37^{\circ} \mathrm{C}, 45 \mathrm{~min}$ 2. DTT

3. LYRAGCLYRAG-Nbz, 8 MPAA, TCEP, $6 \mathrm{M} \mathrm{Gn \cdot HCl}(\mathrm{pH}$ 7.3)<smiles>CC1CC(=O)N(CCCC(=O)NCc2ccccc2)C1=O</smiles>

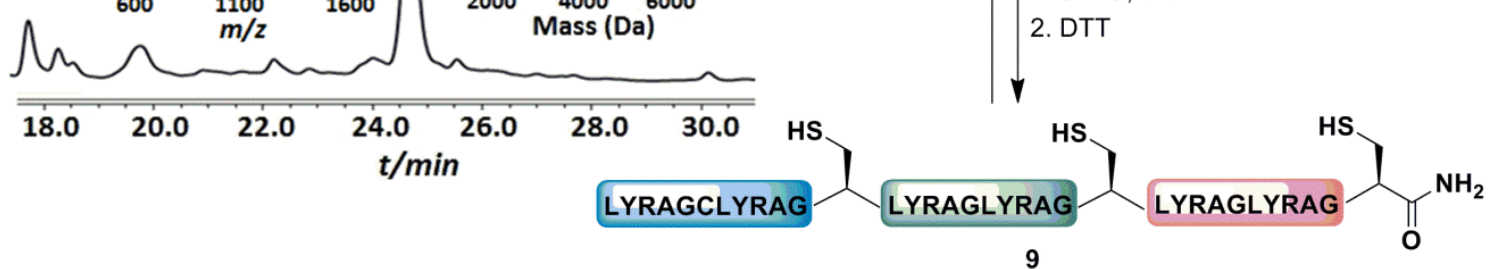

1. $\mathrm{PdCl}_{2}, \mathrm{MgCl}_{2}$

$6 \mathrm{M} \mathrm{Gn} \cdot \mathrm{HCl}, \mathrm{pH} 5.5$

$37^{\circ} \mathrm{C}, 1 \mathrm{~h}$ 
Figure 3. Overview of our SPCL strategy employing maleimide linker (A) The ligation strategy employing immobilization, elongation and release of the peptide from the solid support. HPLC-MS analysis: (B) Crude product after immobilization with an observed mass of $1356.5 \pm 0.1 \mathrm{Da}$ (calcd 1356.6 Da, average isotopes). * corresponds to product of Thz deprotection with an observed mass of 1344.5 $\pm 0.1 \mathrm{Da}$ (calcd 1344.6 Da, average isotopes). (C) Crude product after first ligation with an observed mass of $2580.9 \pm 0.1 \mathrm{Da}$ (calcd 2581.1 Da, average isotopes). * corresponds to product of Thz deprotection with the observed mass of $2568.7 \pm 0.1 \mathrm{Da}$ (calcd $2569.1 \mathrm{Da}$, average isotopes). (D) Crude product after second ligation with an observed mass of 3793.0 $\pm 0.1 \mathrm{Da}$ (calcd 3794.5 Da, average isotopes).

\section{SPCL employing maleimide linker for the synthesis of (Ub-ABPs):}

DUBs are known to cleave the isopeptide bond between the C-terminal glycine residue of $\mathrm{Ub}$ and the ubiquitinated proteins. DUBs play crucial roles in the ubiquitination machinery and are emerging as attractive drug targets. ${ }^{29}$ Therefore, various Ub-ABPs have been developed to study the role of DUBs in health and disease. ${ }^{30}$ Our lab developed a new strategy for the synthesis of Lys-48 and Lys-63 linked di-Ub probes to label different DUBs. ${ }^{31}$ Similarly, we also reported the synthesis of ubiquitinated $\alpha$ globin probe $^{32}$ and ubiquitinated H2A probe $^{15 d}$ for labeling USP15 and Calypso/ASX, respectively. Recently, Champak and coworkers reported the semi synthesis of Ubdehydroalanine (DHA) probe by using selenocysteine as a latent bio-orthogonal electrophile to capture the TRIM-25-associated DUB, ubiquitin-specific protease 15 (USP15). ${ }^{33}$ The Ovaa group demonstrated that Ub-DHA can be used to capture E1-E2-E3 Ub enzymes. ${ }^{34}$ 
Encouraged by the success of the SPCL in producing model system $\mathbf{9}$, we sought to apply these conditions for a more complex system such as Ub-DHA, 14 (Figure 4). Our design for the construction of $\mathbf{1 4}$ by SPCL is shown in Figure 4. The sequence of Ub was divided into three segments, including 10 (Thz-Ub(47-75)-Cys), 11 (Thz-Ub(29-45)Nbz), and 12 (TAMRA-PEG-Ub(1-27)-Nbz), where a fluorophore 5carboxytetramethylrhodamine (TAMRA) was installed at the $\mathrm{N}$-terminal to monitor the DUB capture by using a fluorescent gel (Figure S13). Ala 46 and 28 were temporally replaced with the Thz linkage to enable sequential SPCL. Gly 76 was temporarily mutated to Cys to facilitate the immobilization and late stage DHA formation. With the required segments in hand, the assembly of the polypeptide began with immobilization of peptide segment 10 followed by Thz conversion to the $N$-terminal free Cys. The first ligation was performed with peptide $\mathbf{1 1}$ in the presence of MPAA and TCEP for $8 \mathrm{~h}$ and subsequently the Thz linkage was opened. Similarly, the second ligation was repeated with peptide $\mathbf{1 2}$ for $8 \mathrm{~h}$ and subsequently subjected to desulfurization conditions. After the desulfurization step, the solid support was treated under maleimide deprotection conditions to liberate polypeptide 13, TAMRA-PEG-UbG76C, which was isolated in $37 \%$ overall yield from the 7 steps in under $28 \mathrm{~h}$. Later, the purified polypeptide $\mathbf{1 3}$ was treated with bisamide ${ }^{35}$ to facilitate the formation of Ub-DHA, $\mathbf{1 4}$ in $49 \%$ isolated yield. Following the same protocol, the assembly of Ubv2.3-DHA probe $\mathbf{1 7}$ was obtained in $51 \%$ yield (Figure S16). Ubv2.3 is an engineered Ub variant, known to selectively inhibit USP2, which has C-terminal in close proximity to the catalytic active site. ${ }^{36}$ 
A

TAMRA-PEG-NIEQIFVKTLTGKTITLEVEPSDTIENVKAKIQDKEGIPPDQQRLIFAGKQLEDGRTLSDYNIQKESTLHLVLRLRGC

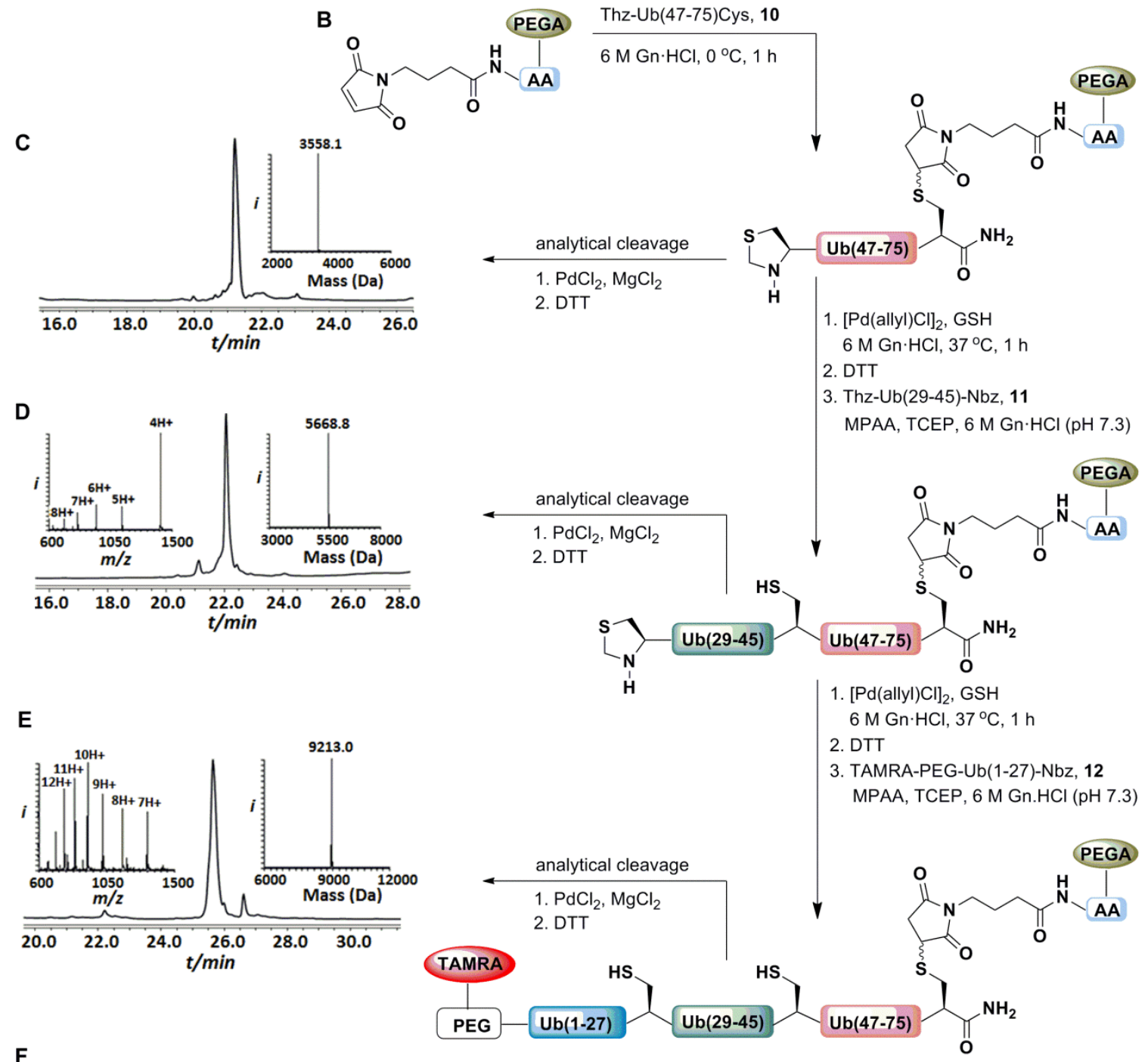

$\mathbf{F}$

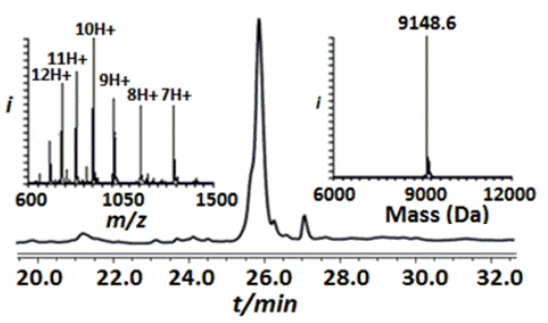

G
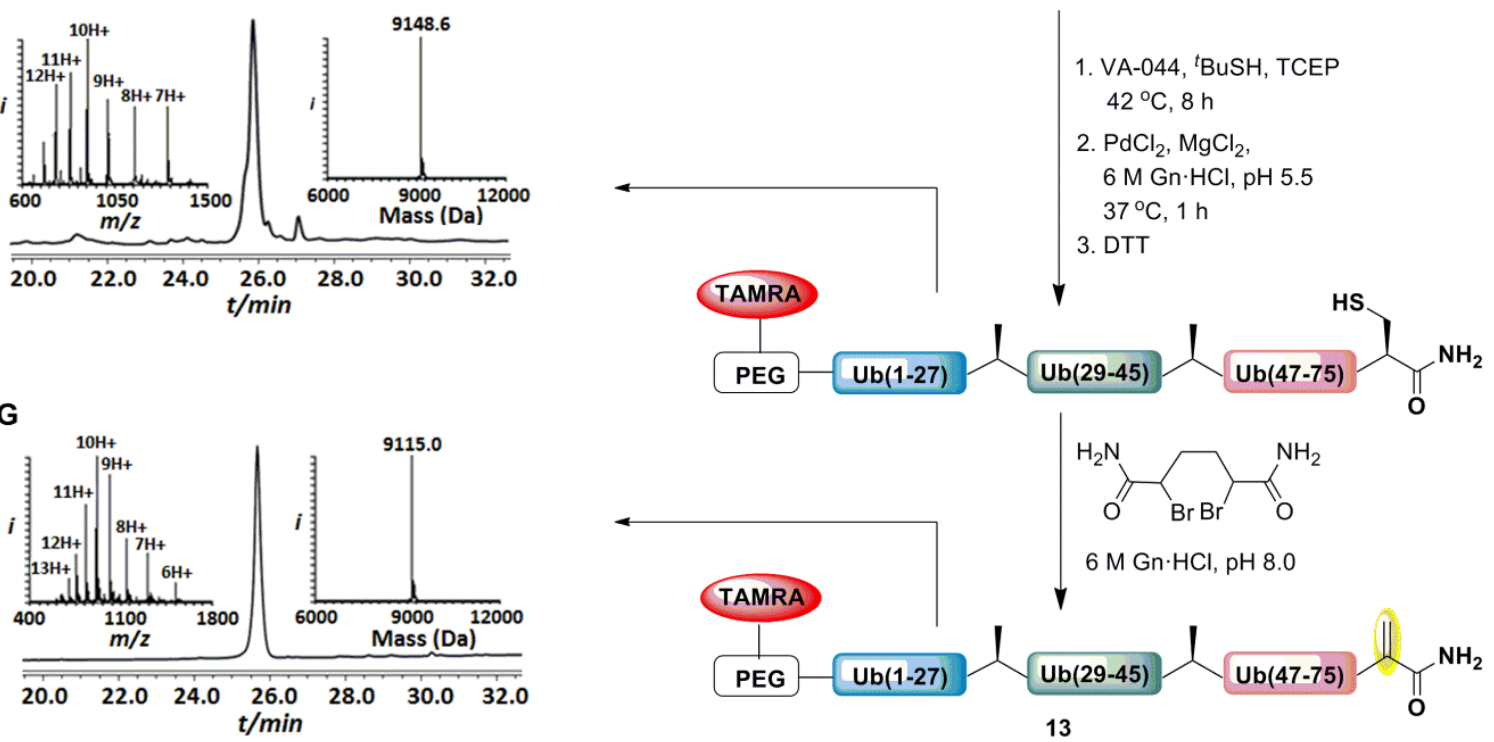
Figure 4. Maleimide group facilitates the SPCL strategy for assembling Ub-DHA probe 14. (A) The sequence of Ub highlighting the ligation sites and different fragments. (B) The ligation strategy employing immobilization, NCL, desulfurization and release of the polypeptide from the solid support and Ub-DHA formation. HPLC-MS analysis: (C) Crude product after immobilization with an observed mass of $3558.1 \pm 0.1 \mathrm{Da}$ (calcd 3558.2 Da, average isotopes). (D) Crude product after first ligation with an observed mass of $5668.8 \pm 0.1 \mathrm{Da}$ (calcd 5668.6 Da, average isotopes). (E) Crude product after second ligation with an observed mass of 9213.0 \pm 0.1 Da (calcd 9213.9 Da, average isotopes). (F) Crude product $\mathbf{1 3}$ after the desulfurization with an observed mass of 9148.6 \pm 0.2 Da (calcd 9149.9 Da, average isotopes). (G) Purified Ub-DHA probe 14 with an observed mass of 9115.0 \pm 0.1 Da (calcd 9115.9 Da, average isotopes).

With both the probes in hand, we then examined selectivity for labeling USP2 compared to USP7- a member of the USP family with high active site similarity to USP2 (Figure 5). We therefore treated our synthetic probes 14 and 17 with the recombinant USP2 and USP7 DUBs and compared their labeling efficiency by fluorescent gel. The labeling experiments showed that the USP2 reacted with Ubv2.3-DHA (17) three times more efficiently than with Ub-DHA (14) (Figure 5B). On the other hand, USP7 almost exclusively labeled Ub-DHA (14) and showed negligible labeling of the Ubv2.3-DHA (17) (Figure 5B). We then proceeded to examine this selectivity in a more complex environment by performing the labeling experiment in cellular lysate. For this study, we chose U2OS cell lines, as they are known to express substantial levels of USP7 and have minimal expression of USP2. ${ }^{37}$ Both synthetic probes 14 and 17 were incubated with the 
cell lysates with or without addition of recombinant USP2 and both demonstrated the appearance of a new fluorescent band after addition of USP2 corresponding to the covalent DUB-Probe formation (Figure 5C). Ubv2.3-DHA, 17 demonstrated mostly USP2 labeling and increased selectivity when compared to the Ub-DHA, 14. We also observed a side reaction corresponding to the labeling of endogenous USP7 with each probe as was confirmed by western blotting with anti-USP7 (Figure 5C). Our strategy can substantially simplify the synthesis of existing complex probes such as Ub-like (Ubl) e.g. SUMO and ISG. 


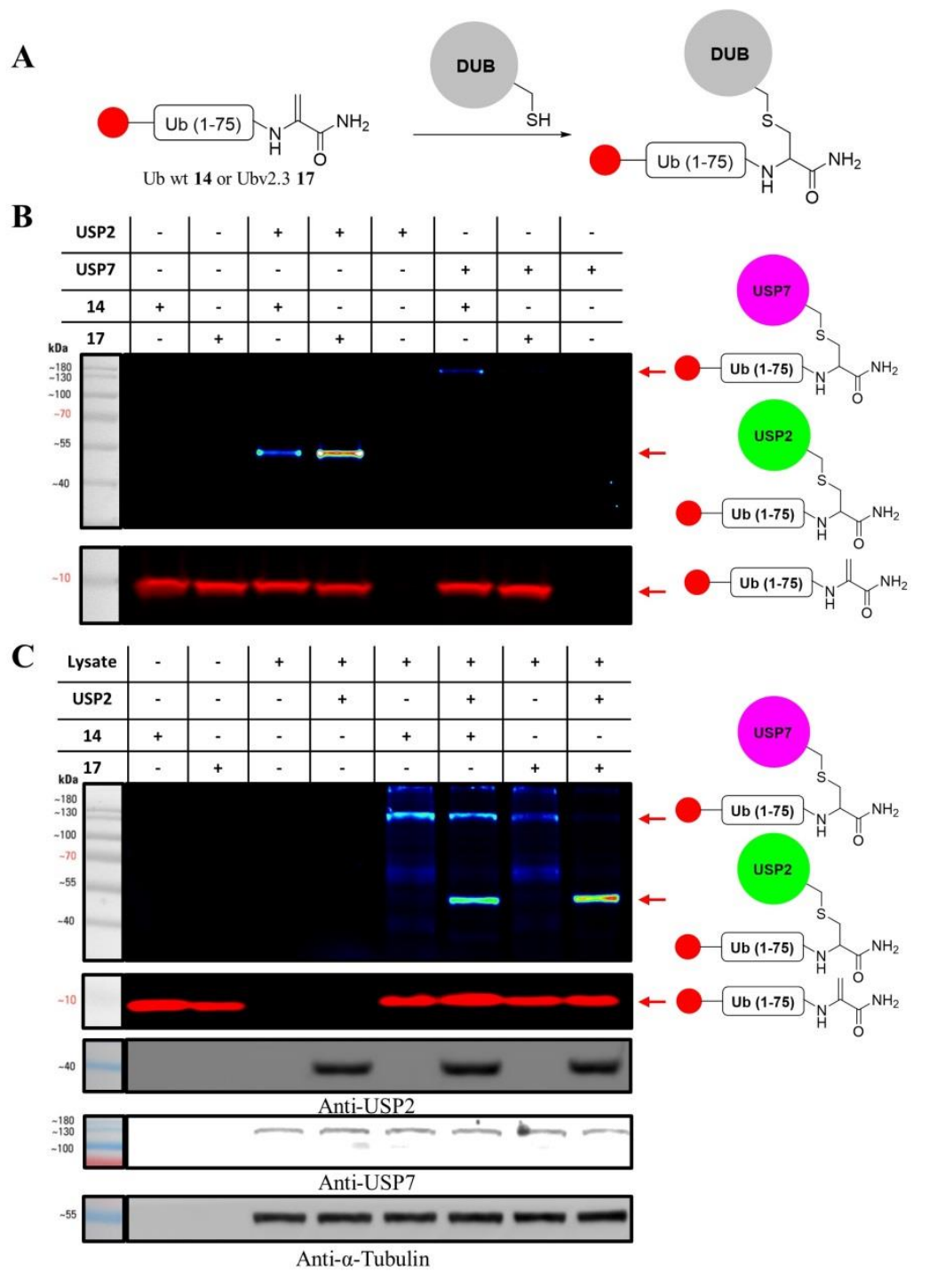

Figure 5. Fluorescent gel of the labeling experiment between two Ub-DHA probes and USP2 / USP7. (A) Schematic reaction between Ub-DHA probes and DUBs of the USP family. (B) Fluorescent gel of the reaction between Ub-DHA probes and purified USP2 and USP7. Top part is an intensity heat map based on TAMRA fluorescence demonstrating the formation of covalent DUB-Probe adducts. Bottom part is the unmodified probe from the same gel as a control for probe loading. (C) Fluorescent gel and western blot of the reaction between Ub-DHA probes and USP2 in U2OS cell lysate with and without USP2. Top part is an intensity heat map based on TAMRA fluorescence 
demonstrating the formation of covalent DUB-Probe adducts followed by the fluorescent image of unmodified probes. Bottom is western blot against USP2, USP7 and $\alpha$-Tubulin (loading control).

\section{Temporal protection of native cysteines to enable selective desulfurization in protein semisynthesis}

Our next goal was to employ maleimide in protein semisynthesis by using it as a temporal PG for a native Cys residue in a peptide thioester following one-pot NCL/desulfurization and final maleimide removal (Figure 6). ${ }^{38}$ However, the protection of free Cys in the presence of a thioester could be challenging as it might lead to thioester hydrolysis. To test this, we synthesized two model peptides 19, LYRAGC $(N-$ Me.Mal)LYRAG-MMP (MMP=methyl 3-mercaptopropionate), bearing C-terminal thioester and 20, Cys-LYRAGLYRAG, bearing $N$-terminal free Cys. Initially, we performed Cys protection in the thioester fragment, 18, at different conditions and found that performing the reaction at $-18{ }^{\circ} \mathrm{C}$ gave the desired maleimide protected thioester, $\mathbf{1 9}$, without any detectable hydrolysis (Figure S17A). These two peptide segments were then ligated to give $\mathbf{2 1}$ and desulfurized to give $\mathbf{2 2}$ in the presence of imidazole ${ }^{39}$ as a non-thiol catalyst and VA-044 for radical desulfurization respectively. ${ }^{40}$ Similar to the SPCL results, the maleimide group was completely stable under imidazole NCL/desulfurization in solution. In the final step, the maleimide group on the Cys residue of $\mathbf{2 2}$ was removed quantitatively under our cleavage conditions to afford polypeptide $\mathbf{2 3}$ in $55 \%$ isolated yield. 
A)

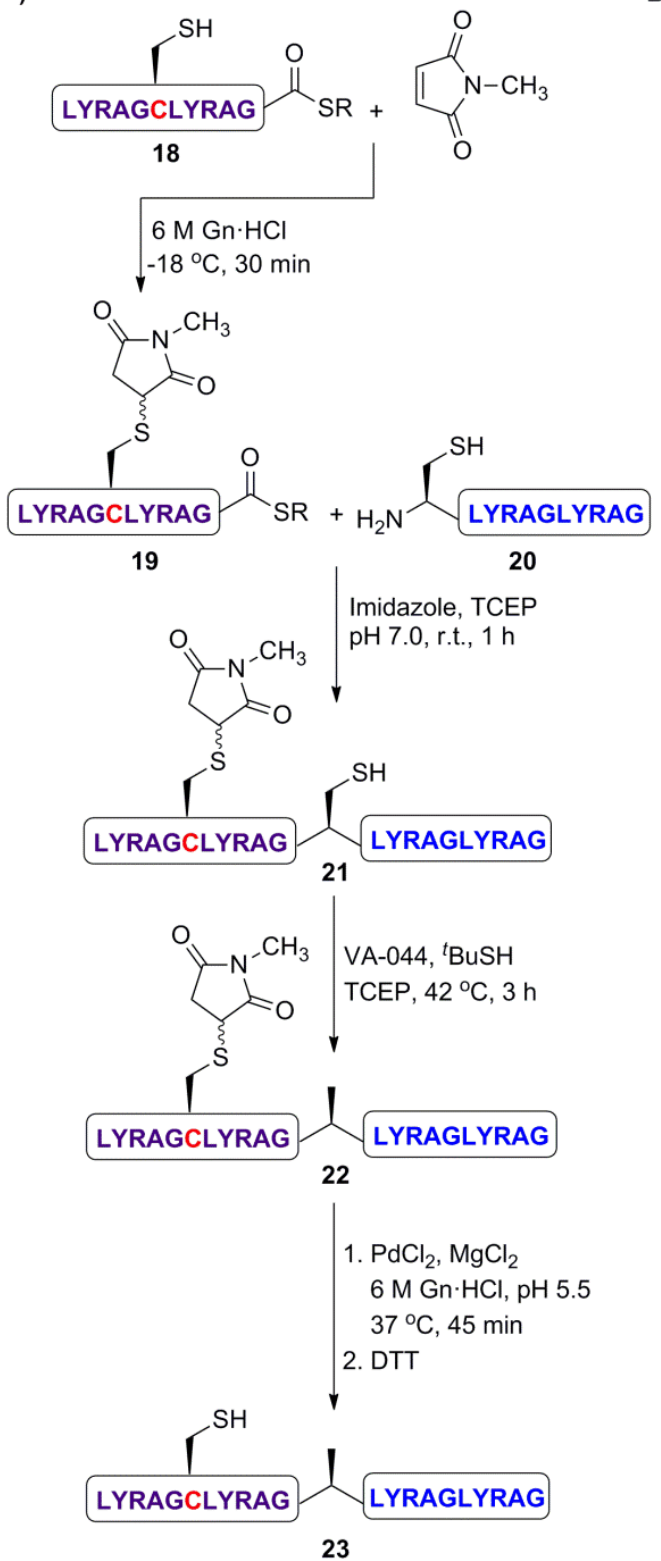

B)

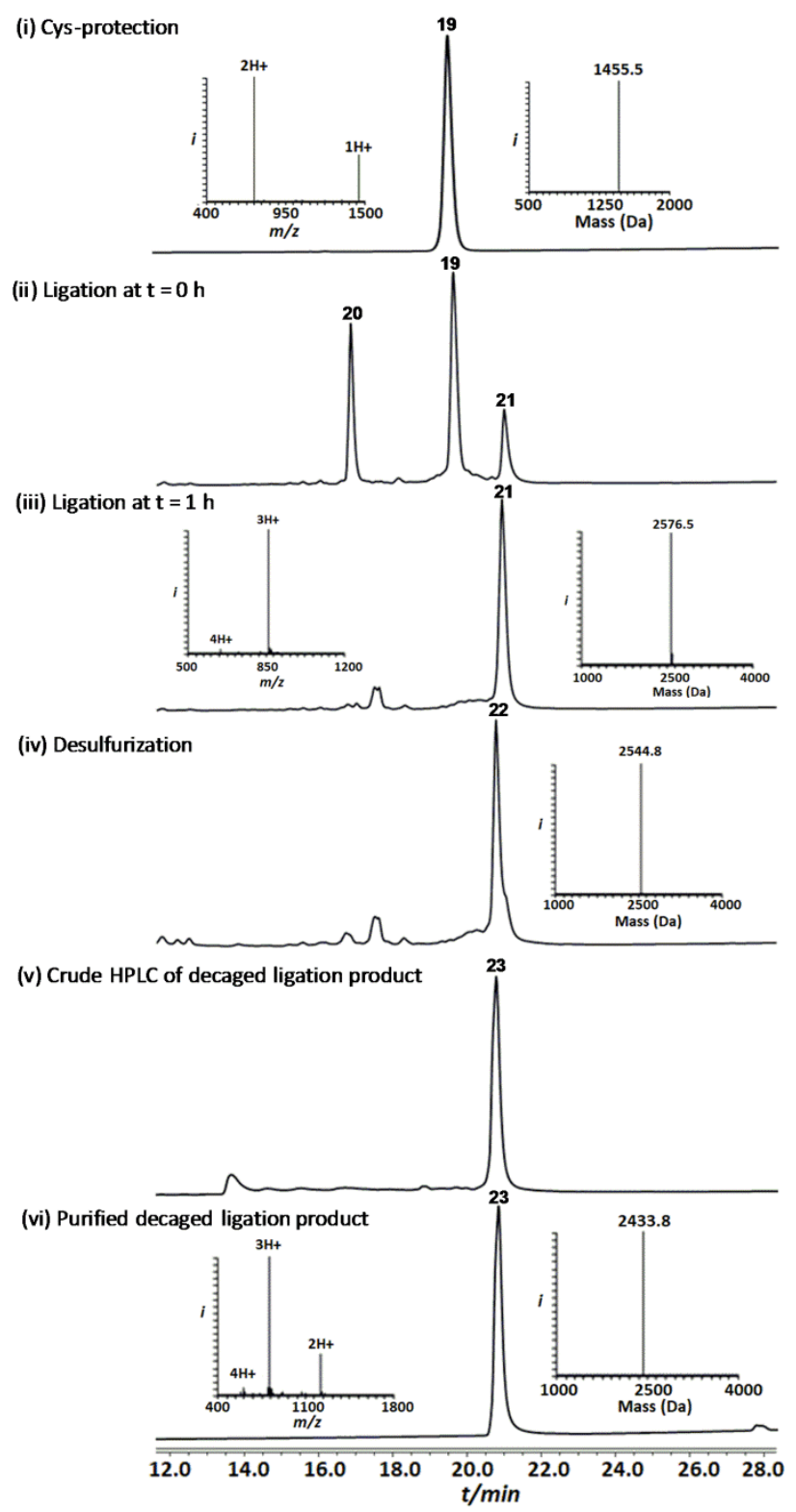

Figure 6. Examining the use of maleimide protection in solution and its stability during $\mathrm{NCL} /$ desulfurization. (A) The ligation strategy employing maleimide protection, one-pot ligation/desulfurization and cleavage the maleimide PG. HPLC-MS analysis: (B) Onepot NCL, desulfurization and maleimide removal. (i) Purified model peptide 19 with an observed mass of $1455.5 \pm 0.1 \mathrm{Da}$ (calcd 1455.5 Da, average isotopes). (ii) Ligation at $\mathrm{t}=$ $0 \mathrm{~h}$, (iii) Ligation at $\mathrm{t}=3 \mathrm{~h}$ with an observed mass of $2576.5 \pm 0.1 \mathrm{Da}$ (calcd 2576.9 Da, 
average isotopes). (iv) Desulfurization product 22 with an observed mass of $2544.8 \pm 0.1$ Da (calcd 2544.9 Da, average isotopes). (v) Crude maleimide cleavage reaction. (vi) Pure polypeptide 23 with an observed mass of $2433.8 \pm 0.1$ Da (calcd 2433.9 Da, average isotopes).

Next, to apply these conditions for a more complex system such as peptides or proteins containing native Cys residues involved in intramolecular disulfide bonds and to check one-pot maleimide deprotection and disulfide bond formation, we used the oxytocin peptide as a model system (Figure S19). The maleimide protected oxytocin was treated under palladium cleavage conditions and subsequently quenched with DTC for $1 \mathrm{~h} .{ }^{16}$ The reaction afforded the desired disulfide bond formation in a one-pot reaction, highlighting the potential use of the maleimide PG for such an approach.

To apply our approach for production of a full semisynthetic protein, we chose E.coli Trx-1 enzyme (Figure 7). Trx-1, a thiol disulfide oxidoreductase which catalyzes the reduction of disulfide bonds in various proteins. ${ }^{41}$ Our design for the semisynthesis of Trx-1 includes a recombinant fragment 24, Trx-1 (2-93)-MESNA ${ }^{42}$ (Figure S20) and a synthetic fragment 25, Cys-Trx-1(95-109) (Figure S21). The recombinant peptide containing $\alpha$-thioester can also be prepared by sortase A via an enzymatic approach. ${ }^{43}$ The recombinant expressed fragment $\mathbf{2 4}$ bearing Cys33 and 36 was protected with the maleimide PG to form $\mathbf{2 6}$ and consecutively ligated ${ }^{44}$ with fragment $\mathbf{2 5}$. The ligation was completed after $4 \mathrm{~h}$ and product 27 was dialyzed against $6 \mathrm{M} \mathrm{Gn} \cdot \mathrm{HCl}$ to facilitate one-pot desulfurization. ${ }^{38} \mathrm{~A}$ free radical desulfurization step and dialysis against $6 \mathrm{M} \mathrm{Gn} \cdot \mathrm{HCl}$ gave 28. Finally, maleimide was removed from the desulfurized product $\mathbf{2 8}$ by $\mathrm{Pd}$ 
treatment and subsequently quenched with DTC for $1 \mathrm{~h}$ to form the oxidized Trx-1, 29 in $34 \%$ isolated yield. Notably, the entire process of the 5 steps was achieved in one-pot. The semi synthetic Trx-1 exhibited the expected secondary structure ${ }^{45}$ (Figure $7 \mathrm{H}$ ) as shown by circular dichroism (CD) and the expected native enzymatic activity using the reported Trx-1 activity assay ${ }^{46}$ (Figure $\left.7 \mathrm{~J}\right)$. 
A

MSDKIIHLTDDSFDTDVLKADGAILVDFWAEWCGPCKMIAPILDEIADEYQGKLTVAKLNIDQNPGTAPKYGIRGIPTLLLFKNGEVAATKVG ALSKGQLKEFLDANLA

C

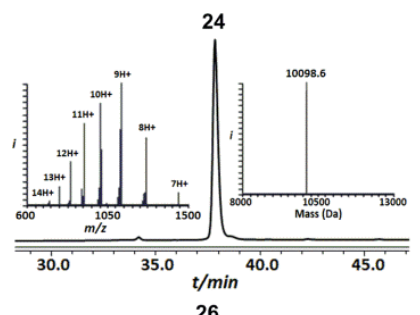

D

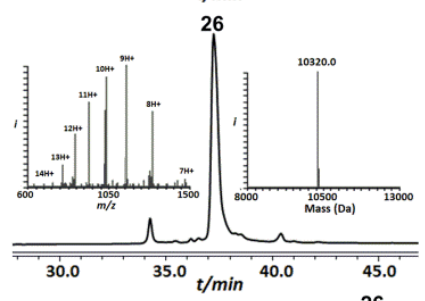

E

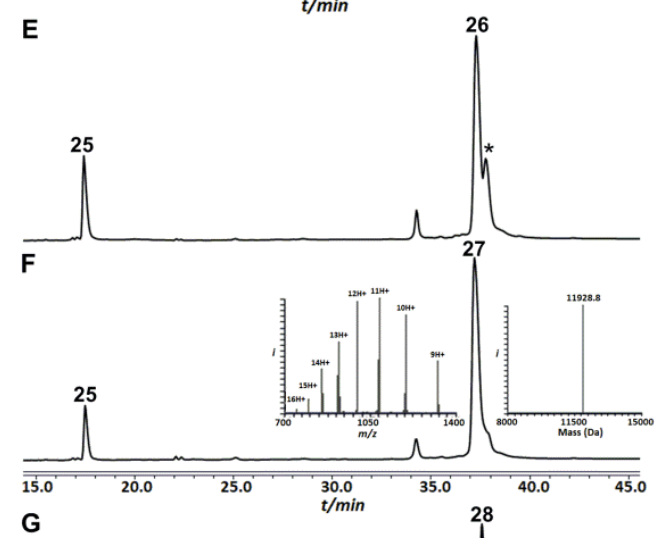

G

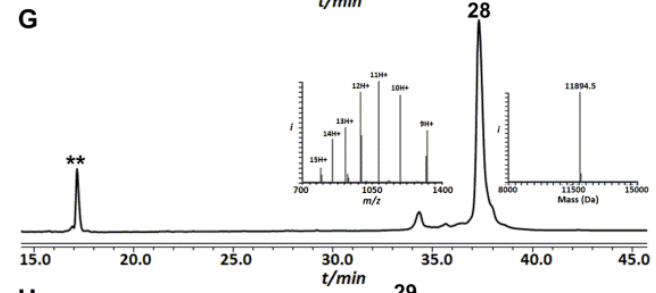

H

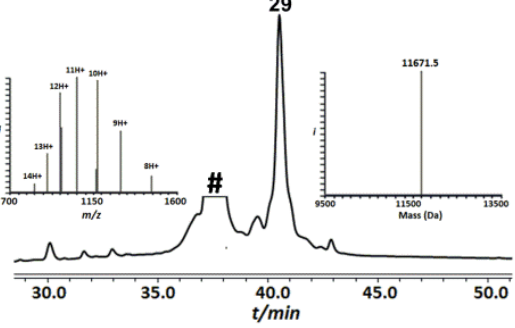

I

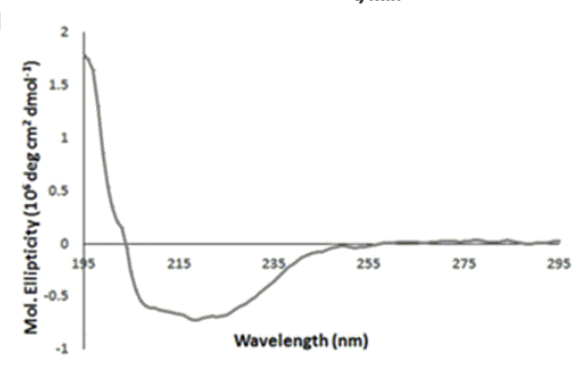

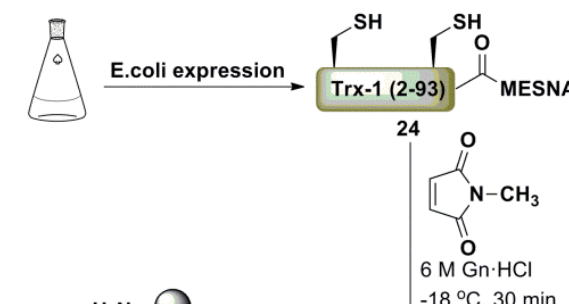
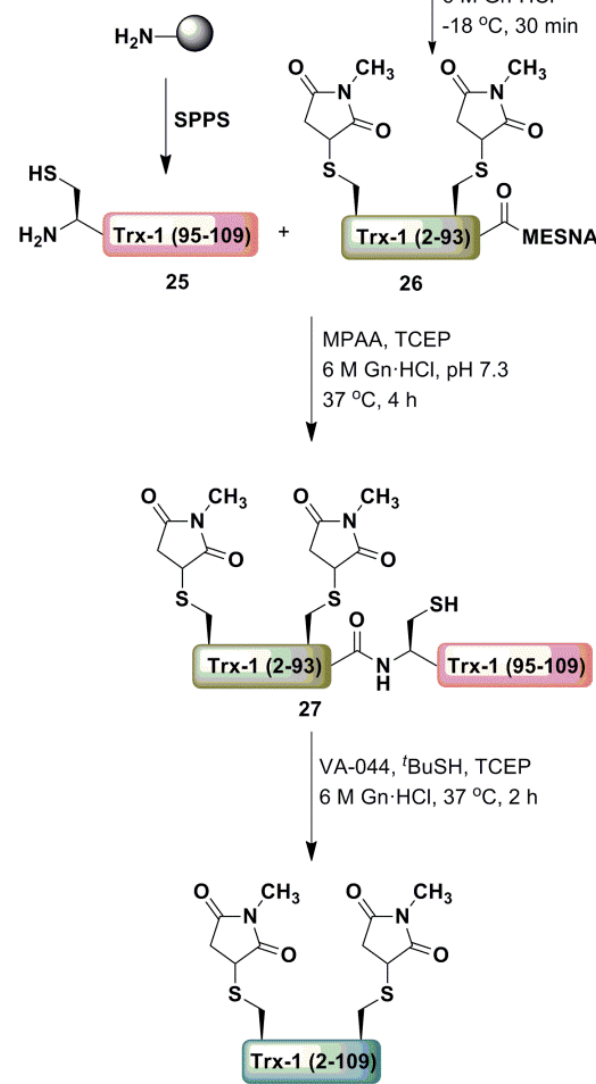

28

1. $\mathrm{PdCl}_{2}, \mathrm{MgCl}_{2}$

$6 \mathrm{M} \mathrm{Gn} \cdot \mathrm{HCl}, \mathrm{pH} 5.5$

$37^{\circ} \mathrm{C}, 45 \mathrm{~min}$

2. DTC

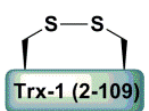

29

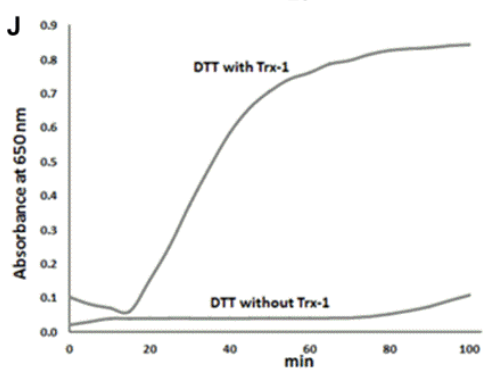


Figure 7. Examining maleimide protection for a recombinant fragment in aqueous solution and expressed protein ligation (EPL). (A) Trx-1 sequence (B) The ligation strategy employing one-pot maleimide protection, EPL/desulfurization, maleimide deprotection and disulfide bond formation. HPLC-MS analysis: (C) Trx-1 (2-93) recombinant fragment with an observed mass of 10098.6 \pm 0.1 Da (calcd 10100.5 Da, average isotopes). (D) Maleimide protected Trx-1 (2-93) recombinant fragment with an observed mass $10320.5 \pm 0.2 \mathrm{Da}$ (calcd 10322.5 Da, average isotopes). (E) Ligation at $\mathrm{t}=$ $0 \mathrm{~h} . *$ is a MPAA-peptide related to thioester fragment. (F) Ligation at $\mathrm{t}=4 \mathrm{~h}$ with an observed mass of $11928.8 \pm 0.2 \mathrm{Da}$ (calcd 11929.5 Da, average isotopes). (G) Crude desulfurization product with an observed mass of $11894.5 \pm 0.8 \mathrm{Da}$ (calcd 11897.5 Da, average isotopes). ${ }^{* *}$ is an unidentified product related to the Cys fragment. (H) HPLCMS analysis of the crude disulfide bond formation with the observed mass of $11671.5 \pm$ 0.2 $\mathrm{Da}$ (calcd 11673.5 $\mathrm{Da}$, average isotopes). \# is a non-peptidic unidentified product related to DTC. (I) CD spectrum of semi-synthesized Trx-1. (J) Semi-synthesized Trx-1 activity assay for reduction of bovine insulin with and without addition of DTT. The change in turbidity of the reaction mixture was analyzed by plotting the absorbance at $650 \mathrm{~nm}$ versus time.

\section{Conclusions}

We have developed for the first time a practical method for the efficient removal of maleimide derivatives by using $\mathrm{Pd}^{\mathrm{II}}$ complexes to enable peptide and protein (semi)synthesis. The synthetic utility of the present method was demonstrated by assembling Ub activity-based probes by SPCL, where the maleimide group was used as a cleavable linker. $\mathrm{Pd}^{\mathrm{II}}$ treatment of the polymer support liberated the polypeptide 
quantitatively with high yield and purity. In addition, we have shown that the maleimide group can be introduced as a protecting group in aqueous solution, especially for recombinant expressed fragments to enable EPL of complex semisynthetic targets. Further, our present protocol successfully facilitated one-pot maleimide detachment and disulfide bond formation under mild conditions. We envision the use of the maleimide group as an orthogonal protecting group and in cleavable solubilizing tags to facilitate peptide and protein synthesis. Furthermore, the maleimide group might find applications in chemical biology as a cleavable linker for anti-body drug conjugates and for proteomics studies.

\section{Supporting Information}

The Supporting Information is available free of charge on the ACS Publications website.

Discussions of materials and methods used, peptide synthesis, removal conditions for maleimide group, orthogonal removal, solid phase chemical ligation, protection of cysteine for recombinant fragments, disulfide bond formation, HPLC and MS data, CD spectrum and enzymatic activity assay.

\section{AUTHOR INFORMATION}

\section{Corresponding Author}

Ashraf Brik - Schulich Faculty of Chemistry, Technion-Israel Institute of Technology, Haifa, 3200008, Israel; orcid.org/0000-0001-8745-2250; Email: abrik@technion.ac.il

\section{Authors}


Ganga B. Vamisetii - Schulich Faculty of Chemistry, Technion-Israel Institute of Technology, Haifa, 3200008, Israel.

Gandhesiri Satish - Schulich Faculty of Chemistry, Technion-Israel Institute of Technology, Haifa, 3200008, Israel.

Prasad Sulkshane - Faculty of Biology, Technion-Israel Institute of Technology, Haifa, 3200008, Israel.

Guy Mann - Schulich Faculty of Chemistry, Technion-Israel Institute of Technology, Haifa, 3200008, Israel.

Mickal H. Glickmann - Faculty of Biology, Technion-Israel Institute of Technology, Haifa, 3200008, Israel.

\section{Author Contributions}

"V.G.B. and G.S. contributed equally.

\section{Notes}

The authors declare no competing financial interest.

\section{Acknowledgements}

This project has received funding from the European Research Council (ERC) under the European Union's Horizon 2020 research and innovation programme (grant agreement no. [831783]). A. B. holds The Jordan and Irene Tark Academic Chair. M. H. G. acknowledges NSF-BSF grant MCB1818280.

\section{References}

1. (a) Paris, C.; Brun, O.; Pedroso, E.; Grandas, A., Exploiting Protected Maleimides to Modify Oligonucleotides, Peptides and Peptide Nucleic Acids. Molecules 2015, 20, 6389 
- 6408. (b) Ravasco, J. M. J. M.; Faustino, H.; Trindade, A.; Gois, P. M. P., Bioconjugation with Maleimides: A Useful Tool for Chemical Biology. Chem. Eur. J. $2019,25,43-59$.

2. (a) Renault, K.; Fredy, J. W.; Renard, P. -Y.; Sabot, C., Covalent Modification of Biomolecules through Maleimide-Based Labeling Strategies. Bioconjugate Chem. 2018, 29, 2497 - 2513. (b) Lee, T. C.; Moran, C. R.; Cistrone, P. A.; Dawson, P. E.; Deniz, A. A., Site-Specific Three-Color Labeling of $\alpha$-Synuclein via Conjugation to Uniquely Reactive Cysteines during Assembly by Native Chemical Ligation. Cell Chem. Biol. 2018, 25, $797-801$.

3. Jain, N.; Smith, S. W.; Ghone, S.; Tomczuk, B., Current ADC Linker Chemistry. Pharm Res. 2015, 32, 3526 - 3540.

4. Manjula, B. N.; Tsai, A.; Upadhya, R.; Perumalsamy, K.; Smith, P. K.; Malavalli, A.; Vandegriff, K.; Winslow, R. M.; Intaglietta, M.; Prabhakaran, M.; Friedman, J. M.; Acharya, A. S., Site-Specific PEGylation of Hemoglobin at Cys-93( $\beta)$ : Correlation between the Colligative Properties of the PEGylated Protein and the Length of the Conjugated PEG Chain. Bioconjugate Chem. 2003, 14, 464 - 472.

5. Mukhortava, A.; Schlierf, M., Efficient Formation of Site-Specific Protein-DNA Hybrids Using Copper-Free Click Chemistry. Bioconjugate Chem. 2016, 27, 1559 1563.

6. (a) Elduque, X.; Pedroso, E.; Grandas, A., Orthogonal Protection of Peptides and Peptoids for Cyclization by the Thiol-Ene Reaction and Conjugation. J. Org. Chem. 2014, 79, 2843 - 2853. (b) Montgomery, J. E.; Donnelly, J. A.; Fanning, S. W.; Speltz, T. E.; Shangguan, X.; Coukos, J. S.; Greene, G. L.; Moellering, R. E., Versatile Peptide 
Macrocyclization with Diels-Alder Cycloadditions. J. Am. Chem. Soc. 2019, 141, 16374 $-16381$.

7. (a) Shen, B. -Q., et al., Conjugation site modulates the in vivo stability and therapeutic activity of antibody-drug conjugates. Nat. Biotechnol. 2012, 30, 184 - 189. (b) Baldwin, A. D.; Kiick, K. L., Tunable degradation of maleimide-thiol adducts in reducing environments. Bioconjugate Chem. 2011, 22, 1946 - 1953. (c) Lyon, R. P., et al., Selfhydrolyzing maleimides improve the stability and pharmacological properties of antibody-drug conjugates. Nat. Biotechnol. 2014, 32, 1059 - 1062.

8. (a) Kalia, D.; Malekar, P. V.; Parthasarathy, M., Exocyclic Olefinic Maleimides: Synthesis and Application for Stable and Thiol-Selective Bioconjugation. Angew. Chem. Int. Ed. 2016, 55, 1432 - 1435. (b) Szijj, P. A.; Bahou, C.; Chudasama, V., Minireview: Addressing the retro-Michael instability of maleimide bioconjugates. Drug Discovery Today: Technologies 2018, 30, $27-34$.

9. (a) Dubowchik, G. M.; Firestone, R. A.; Padilla, L.; Willner, D.; Hofstead, S. J.; Mosure, K.; Knipe, J. O.; Lasch, S. J.; Trail, P. A., Cathepsin B-Labile Dipeptide Linkers for Lysosomal Release of Doxorubicin From Internalizing Immunoconjugates: Model Studies of Enzymatic Drug Release and Antigen-Specific in vitro Anticancer Activity. Bioconjugate Chem. 2002, 13, 855 - 869. (b) Burke, P. J.; Senter, P. D.; Meyer, D. W.; Miyamoto, J. B.; Anderson, M.; Toki, B. E.; Manikumar, G.; Wani, M. C.; Kroll, D. J.; Jeffrey, S. C., Design, Synthesis, and Biological Evaluation of Antibody-Drug Conjugates Comprised of Potent Camptothecin Analogues. Bioconjugate Chem. 2009, $20,1242-1250$. 
10. Rossin, R.; Versteegen, R. M.; Wu, J.; Khasanov, A.; Wessels, H. J.; Steengergen, E. J.; ten Hoeve, W.; Janssen, H. M.; van Onzen, A. H. A. M.; Hudson, P. J.; Robillard, M. S., Chemically triggered drug release from an antibody-drug conjugate leads to potent antitumor activity in mice. Nat. Commun. 2018, 9, 1484.

11. (a) Zhang, Y.; Zhou, X.; Xie, Y.; Greenberg, M. M.; Xi, Z.; Zhou, C., Thiol Specific and Tracelessly Removable Bioconjugation via Michael Addition to 5-Methylene Pyrrolones. J. Am. Chem. Soc. 2017, 139, 6146 - 6151. (b) Nathani, R. I.; Chudasama, V.; Ryan, C. P.; Moody, P. R.; Morgan, R. E.; Fitzmaurice, R. J.; Smith, M. E. B.; Baker, J. R.; Caddick, S., Reversible protein affinity-labelling using bromomaleimide-based reagents. Org. Biomol. Chem. 2003, 11, 2408 - 2411. (c) McConnell, E. W.; Smythers, A. L.; Hicks, L. M., Maleimide-Based Chemical Proteomics for Quantitative Analysis of Cysteine Reactivity. J. Am. Soc. Mass Spectrom. DOI: 10.1021/jasms.0c00116.

12. (a) Bondalapati, S.; Jbara, M.; Brik, A., Expanding the chemical toolbox for the synthesis of large and uniquely modified proteins. Nat. Chem. 2016, 8, $407-418$. (b) Agouridas, V.; El Mahdi, O.; Diemer, V.; Cargoët, M.; Monbaliu, J. -C. M.; Melnyk, O., Native Chemical Ligation and Extended Methods: Mechanisms, Catalysis, Scope, and Limitations. Chem. Rev. 2019, 119, 7328 - 7443. (c) Conibear, A.; Watson, E. E.; Payne, R. J.; Becker, C. F. W., Native Chemical Ligation in Protein Synthesis and SemiSynthesis. Chem. Soc. Rev. 2018, 47, 9046 - 9068.

13. (a) Kumar, K. S. A.; Spasser, L.; Ohayon, S.; Erlich, L. A.; Brik, A., Expeditious Chemical Synthesis of Ubiquitinated Peptides Employing Orthogonal Protection and Native Chemical Ligation. Bioconjugate Chem. 2011, 22, 137 - 143. (b) Siman, P.; Karthikeyan, S. V.; Nikolov, M.; Fischle, W.; Brik, A., Convergent Chemical Synthesis 
of Histone H2B Protein Enabled Site Specific Ubiquitination at Lys34. Angew. Chem. Int. Ed. 2013, 52, 8059 - 8063. (c) Tang, S.; Si, Y. -Y.; Wang, Z. -P.; Mei, K. -R.; Chen, X.; Cheng, J. -Y.; Zheng, J. S.; Liu, L., An Efficient One-Pot Four-Segment Condensation Method for Protein Chemical Synthesis. Angew. Chem. Int. Ed. 2015, 54, $5713-5717$.

14. Jbara, M.; Maity, S. K.; Brik, A., Palladium in the Chemical Synthesis and Modification of Proteins. Angew. Chem. Int. Ed. 2017, 56, 10644 - 10655.

15. (a) Jbara, M.; Maity, S. K.; Seenaiah, M.; Brik, A., Palladium Mediated Rapid Deprotection of N-Terminal Cysteine under Native Chemical Ligation Conditions for the Efficient Preparation of Synthetically Challenging Proteins. J. Am. Chem. Soc. 2016, 138, 5069 - 5075. (b) Maity, S. K.; Jbara, M.; Brik, A., Efficient Palladium-Assisted One-Pot Deprotection of (Acetamidomethyl) Cysteine Following Native Chemical Ligation and/or Desulfurization To Expedite Chemical Protein Synthesis. Angew. Chem. Int. Ed. 2016, 55, 8108 - 8112. (c) Jbara, M.; Eid, E.; Brik, A., Palladium mediated deallylation in fully aqueous conditions for native chemical ligation at aspartic and glutamic acid sites. Org. Biomol. Chem. 2018, 16, 4061 - 4064. (d) Jbara, M.; Laps, S.; Morgan, M.; Kamnesky, G.; Mann, G.; Wolberger, C.; Brik, A., Palladium prompted on-demand cysteine chemistry for the synthesis of challenging and uniquely modified proteins. Nat. Commun. 2018, $9,3154$.

16. Laps, S.; Sun, H.; Kamnesky, G.; Brik, A., Palladium-Mediated Direct Disulfide Bond Formation in Proteins Containing S-Acetamidomethyl-cysteine under Aqueous Conditions. Angew. Chem. Int. Ed. 2019, 58, 5729 - 5733. 
17. Maity, S. K.; Mann, G.; Jbara, M.; Laps, S.; Kamnesky, G.; Brik, A., PalladiumAssisted Removal of a Solubilizing Tag from a Cys Side Chain To Facilitate Peptide and Protein Synthesis. Org. Lett. 2016, 18, 3026 - 3029.

18. (a) Jbara, M.; Laps, S.; Maity, S. K.; Brik, A., Palladium-Assisted Cleavage of Peptides and Proteins Containing a Backbone with Thiazolidine Linkage. Chem. Eur. J. 2016, 22, 14851 - 14855. (b) Mann, G.; Satish, G.; Meledin, R.; Vamisetti, G. B.; Brik, A., Palladium-Mediated Cleavage of Proteins with Thiazolidine-Modified Backbone in Live Cells. Angew. Chem. Int. Ed. 2019, 58, 13540 - 13549.

19. (a) Katayama, H.; Hojo, H., The phenacyl group as an efficient thiol protecting group in a peptide condensation reaction by the thioester method. Org. Biomol. Chem. 2013, 11, 4405 - 4413. (b) Kawakami, T.; Yoshikawa, R.; Fujiyoshi, Y.; Mishima, Y.; Hojo, H.; Tajima, S.; Suetake, I., Synthesis of histone proteins by CPE ligation using a recombinant peptide as the C-terminal building block. J. Biochem. 2015, 158, 403 - 411. (c) Matveenko, M.; Hackel, S.; Becker, C. F. W., Utility of the Phenacyl Protecting Group in Traceless Protein Semisynthesis through Ligation-Desulfurization Chemistry. Chemistry Open 2018, 7, $106-110$.

20. (a) Mochizuki, M.; Hibino, H.; Nishiuchi, Y., Postsynthetic Modification of Unprotected Peptides via S-Tritylation Reaction. Org. Lett. 2014, 16, 5740 - 5743. (b) Mochizuki, M.; Tsuda, S.; Tanimura, K.; Nishiuchi, Y., Regioselective Formation of Multiple Disulfide Bonds with the Aid of Postsynthetic S-Tritylation. Org. Lett. 2015, 17, $2202-2205$. 
21. Lin, Y. A.; Chalker, J. M.; Floyd, N.; Bernardes, G. J. L.; Davis, B. G., Allyl Sulfides Are Privileged Substrates in Aqueous Cross-Metathesis: Application to Site-Selective Protein Modification. J. Am. Chem. Soc. 2008, 130, 9642 - 9643.

22. Lassahn, P. -G.; Lozan, V.; Janiak, C., Palladium (II) salts containing $\left[\mathrm{PdCl}_{4}\right]^{2-}$ and $\left[\mathrm{Pd}_{2} \mathrm{Cl}_{6}\right]^{2-}$ ions as pre-catalysts for the vinyl-polymerization of norbornene-evidence for the in situ formation of $\mathrm{PdCl}_{2}$ as the active species. Dalton Trans. 2003, 927 - 935.

23. Yang, Y., $\beta$-Elimination Side Reactions, Academic Press, San Diego 2016, 33042.

24. Fairlamb, I. J. S.; Kapdi, A. R.; Lynam, J. M.; Taylor, R. J. K.; Whitwood, A. C., Bis(triphenylphosphine)palladium(II)succinimide as a precatalyst for Suzuki crosscoupling subtle effects exerted by the succinimide ligand. Tetrahedron 2004, 60, 5711 5718.

25. (a) Dawson, P. E.; Muir, T. W.; Clark-Lewis, I.; Kent, S. B., Synthesis of proteins by native chemical ligation. Science 1994, 266, 776 - 779. (b) Malins, L. R.; Payne, R. J., Recent extensions to native chemical ligation for the chemical synthesis of peptides and proteins. Curr. Opin. Chem. Biol. 2014, 22, $70-78$.

26. (a) Canne, L. E.; Botti, P.; Simon, R. J.; Chen, Y.; Dennis, E. A.; Kent, S. B. H., Chemical Protein Synthesis by Solid Phase Ligation of Unprotected Peptide Segments. J. Am. Chem. Soc. 1999, 121, 8720 - 8727. (b) Ollivier, N.; Desmet, R.; Drobecq, H.; Blanpain, A.; Boll, E.; Leclercq, B.; Mougel, A.; Vicogne, J.; Melnyk, O., A simple and traceless solid phase method simplifies the assembly of large peptides and the access to challenging proteins. Chem. Sci. 2017, 8, 5362 - 5370. (c) Yu, R. R.; Mahto, S. K.; Justus, K.; Alexander, M. M.; Howard, C. J.; Otteson, J. J., Hybrid phase ligation for efficient synthesis of histone proteins. Org. Biomol. Chem. 2016, 14, $2603-2607$. (d) 
Loibl, S. F.; Harpaz, Z.; Zitterbart, R.; Seitz, O., Total chemical synthesis of proteins without HPLC purification. Chem. Sci. 2016, 7, 6753 - 6759. (e) Jbara, M.; Seenaiah, M.; Brik, A., Solid phase chemical ligation employing a rink amide linker for the synthesis of histone H2B protein. Chem. Commun. 2014, 50, 12534 - 12537. (f) Oliver, R.; Caroline, S. -N.; Hackenberger, C. P. R., Traceless Purification and Desulfurization of Tau Protein Ligation Products. Angew. Chem. Int. Ed. 2015, 54, 306 - 310. (g) Galibert, M.; Piller, V.; Piller, F.; Aucagne, V.; Delmas, A. F., Combining triazole ligation and enzymatic glycosylation on solid phase simplifies the synthesis of very long glycoprotein analogues. Chem. Sci. 2015, 6, $3617-3623$.

27. Meldel, M., Pega: A flow stable polyethylene glycol dimethyl acrylamide copolymer for solid phase synthesis. Tetrahedron Lett. 1999, 33, 3077 - 3080.

28. Blanco-Canosa, J. B.; Nardone, B.; Albericio, F.; Dawson, P. E., Chemical Protein Synthesis Using a Second-Generation N-Acylurea Linker for the Preparation of PeptideThioester Precursors. J. Am. Chem. Soc. 2015, 137, 7197 - 7209.

29. (a) Reyes-Turcu, F. E.; Wilkinson, K. D., Polyubiquitin Binding and Disassembly By Deubiquitinating Enzymes. Chem. Rev. 2009, 109, 1495 - 1508. (b) Pfoh, R.; Lacdao, I. K.; Saridakis, V., Deubiquitinases and the new therapeutic opportunities offered to cancer. Endocr.-Relat. Cancer 2015, 22, T35 - T54.

30. (a) Ekkebus, R.; Flierman, D.; Geurink, P. P.; Ovaa, H., Catching a DUB in the act: novel ubiquitin-based active site directed probes. Curr. Opin. Chem. Bio. 2014, 23, 63 70. (b) Hewings, D. S.; Flygare, J. A.; Wertz, I. E.; Bogyo, M., Activity-based probes for the multicatalytic proteasome. Febs. J. 2017, 284, 1540 - 1554. (c) Gopinath, P.; 
Ohayon, S.; Nawatha, M.; Brik, A., Chemical and semisynthetic approaches to study and target deubiquitinases. Chem. Soc. Rev. 2016, 45, $4171-4198$.

31. Haj-Yahya, N.; Hemantha, H. P.; Meledin, R.; Bondalapati, S.; Seenaiah, M.; Brik, A., Dehydroalanine-Based Diubiquitin Activity Probes. Org. Lett. 2014, 16, 540 - 543.

32. Meledin, R.; Mali, S. M.; Kleifeld, O.; Brik, A., Activity-Based Probes Developed by Applying a Sequential Dehydroalanine Formation Strategy to Expressed Proteins Reveal A Potential $\alpha$-Globin-Modulating Deubiquitinase. Angew. Chem. Int. Ed. 2018, 57, 5645 -5649 .

33. Samuel, D. W.; Markandeya, N.; Rana, A. S. J. B.; Nicholas, A. S.; Caroline, E. W.; Frantisek, T.; Strieter, E. R.; Champak, C., Selenocysteine as a Latent Bioorthogonal Electrophilic Probe for Deubiquitylating Enzymes. J. Am. Chem. Soc. 2016, 138, 13774 13777.

34. Mulder, M. P. C.; Witting, K.; Berlin, I.; NPruneda, J.; Wu, K. -P.; Chang, J. -G.; Merkx, R.; Bialas, J.; Groettrup, M.; Vertegaa, A. C. O.; Schulman, B. A.; Komander, D.; Neefjes, J.; Oualid, F. E.; Ovaa, H., A cascading activity-based probe sequentially targets E1-E2-E3 ubiquitin enzymes. Nat. Chem. Bio. 2016, 12, 523 - 530.

35. Chalker, J. M.; Gunnoo, S. B.; Boutureira, O.; Gerstberger, S. C.; FernandezGonzalez, M.; Bernardes, G. J. L.; Griffin, L.; Hailu, H.; Schofield, C. J.; Davis, B. G., Methods for converting cysteine to dehydroalanine on peptides and proteins. Chem. Sci. 2011, 2, $1666-1676$.

36. Ernst, A.; Avvakumov, G.; Tong, J.; Fan, Y.; Zhao, Y.; Alberts, P.; Persaud, A.; Walker, J. R.; Neculai, A. M.; Neculai, D., et al., A Strategy for Modulation of Enzymes in the Ubiquitin System. Science 2013, 339, 590 - 595. 
37. Uhlén, M.; Fagerberg, L.; Hallström, B. M.; Lindskog, C.; Oksvold, P.; Mardinoglu, A.; Sivertsson, A.; Kampf, C.; Sjöstedt, E.; Asplund, A.; Olsson, I.; Edlund, K.; Lundberg, E.; Navani, S.; Szigyarto, C. A.; Odeberg, J.; Djureinovic, D.; Takanen, J. O.; Hober, S.; Alm, T.; Edqvist, P. H.; Berling, H.; Tegel, H.; Mulder, J.; Rockberg, J.; Nilsson, P.; Schwenk, J. M.; Hamsten, M.; von Feilitzen, K.; Forsberg, M.; Persson, L.; Johansson, F.; Zwahlen, M.; von Heijne, G.; Nielsen, J.; Pontén, F., Tissue-based map of the human proteome. Science 2015, 347, 1260419.

38. Moyal, T.; Hemantha, H. P.; Siman, P.; Refua, M.; Brik, A., Highly efficient one-pot ligation and desulfurization. Chem. Sci. 2013, 4, $2496-2501$.

39. Sakamoto, K.; Tsuda, S.; Mochizuki, M.; Nohara, Y.; Nishio, H.; Yoshiya, T., Imidazole-Aided Native Chemical Ligation: Imidazole as a One-Pot DesulfurizationAmenable Non-Thiol-Type Alternative to 4-Mercaptophenylacetic Acid. Chem. Eur. J. 2016, 22, $17940-17944$.

40. Wan, Q.; Danishefsky, S. J., Free-Radical-Based, Specific Desulfurization of Cysteine: A Powerful Advance in the Synthesis of Polypeptides and Glycopolypeptides. Angew. Chem. Int. Ed. 2007, 46, 9248 - 9252.

41. Ezraty, B.; Gennaris, A.; Barras, F.; Collet, J. F., Oxidative stress, protein damage and repair in bacteria. Nat. Rev. Microbiol. 2017, 15, 385.

42. pTXB1 vector (Catalog\#N6707S, New England Biolabs).

43. Ling, J. J.; Policarpo, R. L.; Rabideau, A. E.; Liao, X.; Pentelute, B. L., Protein Thioester Synthesis Enabled by Sortase. J. Am. Chem. Soc. 2012, 134, 10749 - 10752. 
44. Muir, T. W., Semisynthesis of proteins by expressed protein ligation. Annu. Rev. Biochem. 2003, 72, $249-289$

45. Reutimann, H.; Straub, B.; Luisi, P. L.; Holmgren, A., A conformational study of thioredoxin and its tryptic fragments. J. Biol. Chem. 1981, 256, 6796-6803.

46. Holmgren, A., Thioredoxin catalyzes the reduction of insulin disulfides by dithiothreitol and dihydrolipoamide. J. Biol. Chem. 1979, 254, 9627 - 9632. 
Table of Contents graphics

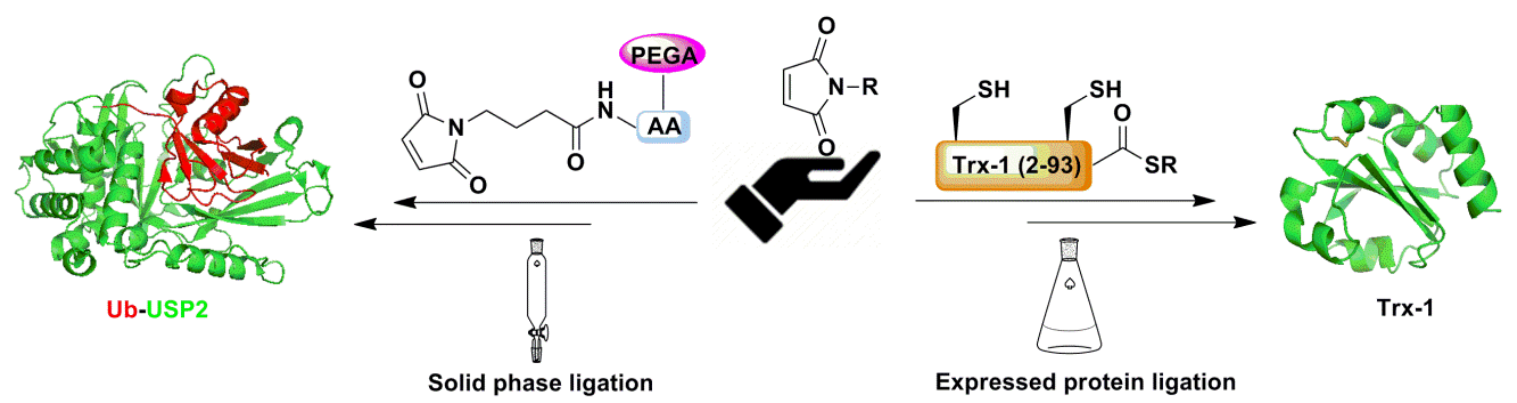

